\title{
DEPENDENCIES BETWEEN CATTLE BREED AND PROFITABILITY OF RAW MILK PRODUCTION
}

\author{
Department of Animal Breeding and Product Quality Assessment, Poznań University of Life Sciences, \\ Poland \\ ${ }^{1}$ Department of Ruminant Science, West Pomeranian University of Technology, Szczecin, Poland
}

\begin{abstract}
The aim of the study was to compare profitability of raw milk production in two herds, one of Jersey cows $(\mathrm{J})$ and the other of Polish Holstein-Friesian Black-and-White cows (PHF), owned by the same economic entity. In this study daily actual and standardised (FCM and VCM) milk yields as well as milk composition were compared between Jersey and PHF cows in terms of age groups (primiparous vs. multiparous cows). Within the Jersey and PHF breeds for each year of the analysed period a balance of revenue and costs from raw milk production was prepared, while production indexes were calculated, i.e. total production cost of 1 I milk, net income from cattle production, net income from the production of 1 I milk, the value of milk production per cow and net income per cow. A more advantageous actual daily milk yield, daily milk yield expressed as FCM and VCM as well as the value of daily milk production were recorded for primiparous PHF cows in comparison to their Jersey peers. In that age group of cows in terms of milk composition, greater contents of fat, protein, solids as well as somatic cell count were found for primiparous Jersey cows. In the case of multiparous cows except for daily FCM and somatic cell count (means did not differ significantly), similar dependencies were recorded for the analysed parameters as those observed for primiparous cows. When comparing profitability indexes for raw milk production in the years 2014-2016 between the Jersey and PHF herds it was shown that in 2014 and 2015, despite lower average milk yields, net income from the production of 1 I milk was the greatest in the Jersey herd, while in 2016 a more advantageous value of this index was recorded for the PHF cows in relation to Jersey cows. In conclusion it may be stated that costs incurred for raw milk production are dependent on specific conditions in a given herd or farm, this it is a rational approach to continuously reduce outlays on milk production combined with improvement of production and functional traits in cows. If the total production costs per 1 I milk in the Jersey and the PHF herds are comparable, greater profitability of raw milk production is observed for Jersey cows. This results from the higher price for sale of milk coming from cows of this breed.
\end{abstract}

Keywords: economics of milk production, Jersey cows, Polish-Holstein-Friesian black-and-white cows.

\section{INTRODUCTION}

Elimination of milk quotas has resulted in strong competition between raw milk producers. They may maintain their position on the market primarily by continuously reducing production costs. Producers are not able to influence milk prices, which are determined mainly by trends on the global dairy market. In turn, at the level of individual farms we may distinguish many

Corresponding author: Ireneusz R. Antkowiak, Department of Animal Breeding and Product Quality Assessment, Poznań University of Life Sciences, Złotniki, Słoneczna 1, 62-002 Suchy Las, Poland, e-mail: irekantk@up.poznan.pl 
factors modifying the volume of outlays incurred to produce 1 I raw milk. One of the measures promoting reduction of milk production costs is related with the continuous herd improvement in terms of the so-called functional traits. In the opinion of Skrzypek (2001), in dairy cattle they include all non-production traits, which may potentially affect milk production costs. Functional traits are connected e.g. with cow health status, reproduction, milking ability, food intake as well as type and confirmation traits. From the point of view of milk production economics the length of productive life is the trait of major importance, since it is connected with the intensity of involuntary culling. At present high-yielding animals with a good health status are preferred in dairy cattle breeding and rearing practice.

A significant role in profitability of raw milk production may also be played by the breed of cows kept in the herd.

The aim of this study was to compare profitability of raw milk production in two cattle herds, one of Jersey cows and the other of Polish Holstein-Friesian Black-and-White cows, both owned by the same economic entity.

\section{MATERIAL AND METHODS}

Source data for this study were collected from the Horse Stud Iwno Sp. z o.o. from the years 2014-2016. In the period of analysis observations were recorded concerning Jersey cows $(\mathrm{J})$ and Polish Holstein-Friesian Black-and-White cows (PHF) in herds of mean annual size of 246 and 458 head, respectively. The cows were kept in the loose housing system. Feed rations were balanced by Schaumann company and administered as TMR. This paper is based on data (RW-1 and RW-2) from milk recording conducted by the Polish Federation of Cattle Breeders and Dairy Farmers as well as annual records on revenue and outlays on milk production.

Actual daily milk production was adjusted to fat-corrected milk (FCM), i.e. milk yield with standardised fat content (4\%) according to Sjaunja et al. (1990), and value-corrected milk (VCM) according to Arbel et al. (2001).

In this study the actual and standardised daily milk yields (FCM and VCM) and milk composition were compared between Jersey and Polish Holstein-Friesian cows taking into consideration division into age groups (primiparous vs. multiparous cows). Within the Jersey and PHF breeds for each year of the analysis the revenue and costs of raw milk production were compared. Moreover, production indexes were calculated, i.e. total production cost per 1 I milk, net income from cattle production, net income from the production of 1 I milk, the value of milk production per cow as well as net income per cow.

Costs related with raw milk production were divided into 3 groups: overheads (services, fuel and electricity, water, wages, medication for animals, insurance, maintenance and repairs of animal housing facilities as well as other outlays), costs generated by purchase of feeds produced by entities other than Stadnina Koni Iwno Sp. z o.o. and costs related with equipment depreciation.

Indexes concerning profitability of raw milk production were calculated using the following formulas:

1) total production cost of $1 \mathrm{I}$ milk = total costs $/$ milk produced, 
2) net income from cattle production = total revenue - total costs,

3) net income from the production of $1 \mathrm{I}$ milk = mean annual milk price - total production cost of 1 I milk,

4) value of production per cow = value of milk production/mean annual head count,

5) net income per cow = net income from the production/ mean annual head count.

Statistical analyses were conducted using the SAS ${ }^{\circledR}$ software package (2016). Basic statistical parameters were calculated applying the MEANS procedure. The significance of the effect of experimental factors (year, season, calving group, breed, origin of the sire, milking day in lactation, daily milk yield) was analysed using the multivariate analysis of covariance applying the SAS-GLM procedure, according to the following linear model:

$Y_{i j k l m n o}=\mu+r_{i}+s_{j}+l_{k}+r_{1}+k_{m}+\beta_{1} d_{n}+\beta_{2} w_{m_{o}}+e_{i j k l m n o}$ where:

$\mathrm{Y}_{\mathrm{ijk} k \mathrm{mno}}$ - phenotypic value of analysed trait,

$\mu$ - population mean,

$r_{i}-$ fixed effect of $i$-th year $(i=1,2,3)$,

$s_{j}-$ fixed effect of $j$-th season $(j=1,2,3,4)$,

$\mathrm{I}_{\mathrm{k}}$ - fixed effect of $\mathrm{k}$-th calving group $(\mathrm{k}=1,2)$,

$r_{1}-$ fixed effect of $I-$ th breed $(I=1,2)$,

$k_{m}-$ fixed effect of $m$-th origin of sire $(m=1,2,3)$,

$\beta_{1}, \beta_{2}-1$ st order partial linear regression coefficients,

$d_{n}$ - milking day in lactation,

$\mathrm{wm}_{\mathrm{o}}$ - daily milk yield in lactation,

$\mathrm{e}_{\mathrm{ijk} \mathrm{j} m \mathrm{mo}}$ - random error.

To compare object means several multiple comparisons were performed using Tukey's test.

\section{RESULTS}

Table 1 presents a comparison of daily yield, milk composition and the value of raw milk production for $\mathrm{J}$ and PHF cows in terms of the age groups of animals. The analysis showed significant differences $(P \leq 0.05)$ between primiparous cows for all the investigated traits. A more advantageous actual daily milk yield, daily milk yield in terms of FCM and VCM as well as the value of daily milk production were found for primiparous PHF cows in relation to their Jersey peers. In this age group of cows taking into consideration milk composition greater contents of fat, protein, milk solids and somatic cell count were recorded for primiparous Jersey cows. Except for daily FCM yield and somatic cell count (SCC) in milk (means did not differ significantly) in the case of multiparous cows similar dependencies were obtained for the investigated parameters as those recorded for primiparous cows. For the analysed traits many statistically significant differences (at $P \leq 0.05$ ) were found within breeds when comparing age groups. Multiparous cows were characterised by greater values of the investigated parameters. However, primiparous cows and multiparous cows in the PHF breed did not differ in terms of the contents of fat, protein and solids in their milk. In the case of Jersey cows a similar dependence was observed for lactose content in milk. 
Table 1. Traits of daily milking performance in Jersey and Polish Holstein-Friesian Blackand-White (PHF) cows in analysed herds in the years 2014-2016

\begin{tabular}{|c|c|c|c|c|c|}
\hline \multirow{2}{*}{ Traits } & \multirow{2}{*}{ Breed } & \multicolumn{2}{|c|}{ Primiparous cows } & \multicolumn{2}{|c|}{ Multiparous cows } \\
\hline & & $\bar{x}$ & SD & $\bar{x}$ & SD \\
\hline \multirow{2}{*}{ Milk [kg] } & Jersey & $20.9 \mathrm{~A} A$ & 43.14 & $24.7 \mathrm{AB}$ & 43.13 \\
\hline & PHF & $28.9 \mathrm{BA}$ & 43.32 & $31.7 \mathrm{BB}$ & 43.23 \\
\hline \multirow{2}{*}{ FCM [kg] } & Jersey & $24.6 \mathrm{~A} A$ & 43.14 & $28.4 \mathrm{AB}$ & 43.20 \\
\hline & PHF & $27.5 \mathrm{~B} A$ & 42.34 & $30.2 \mathrm{BB}$ & 43.29 \\
\hline \multirow{2}{*}{ VCM $[\mathrm{kg}]$} & Jersey & $30.2 \mathrm{~A} A$ & 43.28 & $35.0 \mathrm{AB}$ & 43.28 \\
\hline & PHF & $33.1 \mathrm{~B} A$ & 43.16 & $36.2 \mathrm{BB}$ & 43.20 \\
\hline \multirow{2}{*}{ Value of daily milk production [PLN] } & Jersey & $29.70 \mathrm{~A} A$ & 45.11 & $33.48 \mathrm{AB}$ & 17.38 \\
\hline & PHF & $38.52 \mathrm{BA}$ & 43.23 & $40.96 \mathrm{BB}$ & 13.58 \\
\hline \multirow{2}{*}{ Value of daily FCM production [PLN] } & Jersey & $34.87 \mathrm{~A} A$ & 41.46 & $38.37 \mathrm{AB}$ & 26.51 \\
\hline & PHF & $36.55 \mathrm{BA}$ & 31.23 & $38.93 A B$ & 19.33 \\
\hline \multirow{2}{*}{ Value of daily VCM production [PLN] } & Jersey & $42.80 \mathrm{~A} A$ & 30.50 & $47.28 \mathrm{AB}$ & 12.33 \\
\hline & PHF & 43.94 BA & 18.11 & $46.61 \mathrm{BB}$ & 13.67 \\
\hline \multirow{2}{*}{ Fat [\%] } & Jersey & $5.26 \mathrm{~A} A$ & 0.69 & $5.06 \mathrm{AB}$ & 0.77 \\
\hline & PHF & $3.74 \mathrm{BA}$ & 0.71 & $3.75 \mathrm{BA}$ & 0.76 \\
\hline \multirow{2}{*}{ Protein [\%] } & Jersey & $4.08 \mathrm{~A} A$ & 0.45 & $4.02 \mathrm{AB}$ & 0.40 \\
\hline & PHF & $3.41 \mathrm{BA}$ & 0.36 & $3.41 \mathrm{BA}$ & 0.37 \\
\hline \multirow{2}{*}{ Lactose [\%] } & Jersey & $4.84 \mathrm{~A} A$ & 0.15 & $4.76 \mathrm{~A} A$ & 0.31 \\
\hline & PHF & $4.93 \mathrm{BA}$ & 0.18 & $4.81 \mathrm{BB}$ & 0.23 \\
\hline \multirow{2}{*}{ Milk solids [kg] } & Jersey & $14.88 \mathrm{~A} A$ & 0.99 & $14.66 \mathrm{AB}$ & 43.19 \\
\hline & PHF & $12.73 \mathrm{BA}$ & 0.95 & $12.66 \mathrm{BA}$ & 43.13 \\
\hline \multirow{2}{*}{ SCC [thous./ml] } & Jersey & $142 \mathrm{~A} A$ & 88 & $160 A B$ & 98 \\
\hline & PHF & $124 \mathrm{BA}$ & 94 & $154 A B$ & 103 \\
\hline
\end{tabular}

Means denoted with identical letters do not differ statistically at $P \leq 0.05$.

$\mathrm{A}, \mathrm{B}$ - comparison within the column for breeds within the age group.

$A, B$ - comparison in the row for age groups within the breed.

Tables 2 and 3 present revenue and costs as well as profitability indexes for raw milk production in the years 2014-2016 for the Jersey and PHF breeds. In the case of Jersey cows (Table 2) the lowest revenue from milk production (2 354096.61 PLN) was reported in 2014. However, in the same year the highest price for 1 I milk (1.69 PLN) was obtained, while the total milk production costs were the lowest (1 897266.91 PLN) in comparison to the years 2015-2016. When analysing the components of outlays on milk production in the Jersey herd it was stated that in 2014 in relation to the two successive years overheads were the highest, while costs related with depreciation were the lowest. Analyses of values for profitability indexes of raw milk production showed that the value of production per cow and net income per cow were the highest in 2014. Although total costs of producing 1 I milk were the highest in 2014 (1.24 PLN), net income from the production 1 I milk in the Jersey herd (0.25 PLN) was greater than that in 2015-2016, i.e. 0.22 and 0.10 PLN, respectively. 
Table 2. Revenue, costs and profitabiity indexes for raw milk production in the Jersey herd in the years 2014-2016

\begin{tabular}{|c|c|c|c|}
\hline \multirow{2}{*}{ Specification } & \multicolumn{3}{|c|}{ Years } \\
\hline & 2014 & 2015 & 2016 \\
\hline \multicolumn{4}{|c|}{ Revenue } \\
\hline Mean annual head count & 223 & 263 & 261 \\
\hline Milk produced [l] & 1532419 & 1816684 & 1798680 \\
\hline Milk sold [l] & 1449284 & 1786575 & 1742379 \\
\hline Price of 1 I milk sold [PLN] & 1.49 & 1.33 & 1.31 \\
\hline Other revenue [PLN] & - & 12764.52 & 14677.80 \\
\hline Value of milk production [PLN] & 2159433.16 & 2376144.75 & 2282516.49 \\
\hline Cattle on hoof and culled animals [PLN] & 194662.85 & 190336.00 & 205150.20 \\
\hline$\Sigma$ & 2354096.01 & 2579245.27 & 2502344.49 \\
\hline \multicolumn{4}{|c|}{ Costs } \\
\hline Overheads [PLN] & 1239156.72 & 1112596.74 & 1194735.78 \\
\hline Purchased feeds [PLN] & 624245.63 & 746438.17 & 801091.58 \\
\hline Depreciation costs [PLN] & 33864.56 & 165521.42 & 175145.61 \\
\hline$\Sigma$ & 1897266.91 & 2024556.33 & 2170972.97 \\
\hline \multicolumn{4}{|c|}{ Production profitability indexes } \\
\hline Total production cost of 1 I milk [PLN] & 1.24 & 1.11 & 1.21 \\
\hline Net income from the production bydła [PLN] & 456829.10 & 554688.94 & 331371.52 \\
\hline Net income from the production of 1 I milk [PLN] & 0.25 & 0.22 & 0.10 \\
\hline Value of production per cow [PLN] & 9683.56 & 9034.77 & 8745.27 \\
\hline Net income per cow [PLN] & 2048.56 & 2109.08 & 1269.62 \\
\hline
\end{tabular}

Table 3. Revenue, costs and profitability indexes of raw milk production in the Polish Holstein-Friesian Black-and-White herd in the years 2014-2016

\begin{tabular}{|c|c|c|c|}
\hline \multirow{2}{*}{ Specification } & \multicolumn{3}{|c|}{ Years } \\
\hline & 2014 & 2015 & 2016 \\
\hline \multicolumn{4}{|c|}{ Revenue } \\
\hline Mean annual head count & 455 & 442 & 474 \\
\hline Milk produced [l] & 3945515 & 3830131 & 4232073 \\
\hline Milk sold [l] & 3833194 & 3722045 & 4121640 \\
\hline Price of 1 I milk sold [PLN] & 1.42 & 1.22 & 1.22 \\
\hline Other revenue $[\mathrm{PLN}]$ & 33531.46 & 172690.41 & 11508.60 \\
\hline Value of milk production [PLN] & 5443135.48 & 4540894.90 & 5028400.80 \\
\hline Cattle on hoof and culled animals [PLN] & 358766.20 & 335081.20 & 321104.50 \\
\hline$\Sigma$ & 5835433.14 & 5048666.51 & 5361013.90 \\
\hline \multicolumn{4}{|c|}{ Costs } \\
\hline Overheads [PLN] & 3138517.62 & 2553313.60 & 2626236.25 \\
\hline Purchased feeds [PLN] & 1555111.34 & 1359694.60 & 1642924.81 \\
\hline Depreciation costs [PLN] & 347253.96 & 348003.54 & 347012.33 \\
\hline$\Sigma$ & 5040882.92 & 4261011.74 & 4617164.60 \\
\hline \multicolumn{4}{|c|}{ Production profitability indexes } \\
\hline Total production cost of 1 I milk [PLN] & 1.28 & 1.11 & 1.09 \\
\hline Net income from the production bydła [PLN] & 794550.22 & 787654.77 & 743849.30 \\
\hline Net income from the production of 1 I milk [PLN] & 0.14 & 0.11 & 0.13 \\
\hline Value of production per cow [PLN] & 11962.94 & 10273.52 & 10608.44 \\
\hline Net income per cow [PLN] & 1746.26 & 1782.02 & 1569.30 \\
\hline
\end{tabular}


In the case of milk production in the PHF herd (Table 3 ) the highest values of total revenue (5 835433.14 PLN), costs (5 040882.92 PLN) and outlays per 1 I milk produced (1.28 PLN) were recorded in 2014. Although the price per $1 \mathrm{I}$ milk in that year was the highest (1.42 PLN) in relation to the years 2015-2016, in terms of profitability indexes the net income from the production of $1 \mathrm{I}$ milk in 2014 and 2016 was comparable, amounting to 0.14 and 0.13 PLN, respectively. In turn, in 2015 the value of this index was lower, as it was 0.11 PLN per 1 I milk. A comparison of profitability indexes for raw milk production in the years 2014-2016 between the Jersey and PHF herds showed that net income from the production of 1 I milk was greatest in the Jersey herd in 2014 and 2015, amounting to 0.25 and 0.22 PLN, respectively. In turn, in 2016 a more advantageous value of this index (0.13 PLN) was recorded for PHF cows in comparison to Jersey cows (0.10 PLN).

\section{DISCUSSION}

In the opinion of Muhammad et al. (2017) various dependencies are found between income, prices and food consumption. For this reason currently produced food needs to be rich in nutrients, culturally acceptable and produced at the slightest possible interference into natural resources and the environment. Such conditions are met e.g. by milk, yoghurts and other dairy products, characterised by relatively high concentrations of nutrients in comparison to plant origin foodstuffs (Drewnowski 2018). For this reason raw milk production and its processing have good prospects for future development. It is generally known that profitability of raw milk production is influenced by such factors as herd size, adopted production technology, average yield per cow and milk wholesale prices. In many countries milk production is increasing at the growing average milk yields and a considerable reduction in the number of cows and milk suppliers. In the opinion of Wolf (2003), an increase in herd size and consolidation of production results from the allocation of capital, labour and outlays for management to a larger number of milk production units. Costs of milk production decrease in large herds (Hadley et al. 2002). A study by Mosheim and Lovell (2009) conducted in the USA confirmed changes in the size of dairy farms, which have been successively increasing.

It is generally known that Holstein-Friesian cattle are characterised by high milk yields, while Jersey cows have a particularly advantageous milk composition in terms of its processability and more desirable functional traits. In this study a comparison of animals of both these breeds in terms of daily milk yield and milk composition (Table 1) showed that PHF cows in comparison to Jersey cows were characterised by higher daily milk yields, whereas in terms of contents of milk solids, fat and protein more advantageous values were found for Jersey cows. Similar results in earlier studies conducted on Jersey cows and Black-and-White cows with a high share of HF genes in their genotype were recorded by Antkowiak (1996) and Litwińczuk and Barłowska (2002). In the opinion of De Vries (2018), genetic improvement is of significance, although it does not guarantee extensive longevity of cows. Economic longevity of cows still depends on the reduction of value of the animals rather than accelerated improvement of genetic value of heifers. Longevity connected with superior health condition and productivity is a highly desirable trait in cattle. It was shown that 
a threat of cow mortality is related to many factors, e.g. the adopted animal management system, business management practices, breed and the size of a given animal (Sarjokari et al. 2018).

Analyses were conducted on the balance of revenue and costs as well as the calculated values of profitability indexes for milk production in the years 2014-1016 for the Jersey herd (Table 2) and the PHF herd (Table 3). In the case of the PHF herd total production costs per 1 I milk decreased in the successive analysed years, although the highest outlays for purchased feeds were recorded in 2016. A similar dependence for the Jersey herd was found only in the years 2014-2015. Such a result for the Jersey herd most probably resulted from the fact that an over 5 -fold increase in costs incurred for depreciation and an over $28 \%$ increase in outlays for feed purchases was recorded in 2016 in relation to 2014. Analyses conducted by Chen and Holden (2018) showed that the financial cost for the production of 1 I milk in Ireland in 2013 was EUR 0.53. At the same time those authors were of an opinion that total outlays for the production of 1 I milk may be higher. Krpàlkovà et al. (2017) reported that in the Czech Republic for high-yielding herds (over 9 thousand $\mathrm{kg} / \mathrm{head}$ ) the cost of production per 1 I milk was EUR 0.32. In the opinion of Okularczyk (2004), the main factor influencing profitability of milk production is related with the share of feed produced on farm in relation to all used feeds. It is also known that high-yielding cows consume greater amounts of concentrates, which are the most expensive feeds.

A significant role is played by disease control and adequate prophylaxis. In the opinion of Hogeveen et al. (2017), prevention particularly of endemic diseases (e.g. mastitis) minimises total costs incurred in animal production. According to Kossaibati and Esslemont (1997), in England mastitis and lameness were the main health problems in Holstein-Friesian cows, accounting for 38 and $27 \%$ healthcare costs, respectively. However, in the opinion of Seegers et al. (2003) the economic problem related with mastitis has to be solved at the farm level and depends on local and regional epidemiological conditions as well as management practices. Increased costs of milk production result also from the incidence of metabolic diseases. Based on their investigations conducted in Holland Mostert et al. (2018) reported that subclinical ketosis and the related health conditions generate average annual costs per 1 case amounting to EUR 130 (ranging from EUR 39 to EUR 348).

In terms of net income from the production of $1 \mathrm{I}$ milk in the Jersey herd the values of this index in 2014 and 2015 were comparable to the mean values for this parameter reported by Pytlewski et al. (2017) in the population of PHF cows in the period before and after Poland's accession to the EU ( 0.21 and 0.23 PLN, respectively). In turn, in earlier studies conducted by Pytlewski et al. (2014) in 2001-2012 in a herd of 100 PHF cows the profit ratio from the production of 1 I milk was higher, ranging from 0.31 PLN to 0.59 PLN.

Summing up it needs to be stated that profitability of raw milk production varied in the investigated period in the two dairy cow herds. It was shown that in the years 2014-2015, despite lower average milk yields, a greater net income from the production of 1 I milk was reported for Jersey cows in comparison to Polish Holstein-Friesian Black-and-White cows. Such a result most probably resulted from the higher price for the sale of 1 I milk produced in the Jersey herd. In turn, in 2016 more advantageous net income from the production of 1 I milk was obtained from Polish Holstein-Friesian Black-and-White cows. Such a result 
most probably resulted from an increase (by $9 \%$ ) in total costs per $1 \mathrm{I}$ milk produced and a decrease (by 40\%) in net income per cow in relation to the previous year in the Jersey herd. In the Jersey herd in 2016 the marked reduction of net income from the production of 1 I milk (by 0.12 PLN) in relation to 2015 was caused by an increase in milk production costs and lower revenue per 1 I sold milk.

\section{CONCLUSIONS}

1. Costs incurred for raw milk production are dependent on specific conditions found in a given herd or farm, thus it is a rational practice to continuously reduce outlays on its production combined with improvement of production and functional traits in cows.

2. If the total production cost of $1 \mathrm{I}$ milk in the Jersey herd and in the Polish Holstein-Friesian Black-and-White herd is comparable, greater profitability of raw milk production is found for Jersey cows. This results from the higher price obtained for the sale of milk coming from cows of that breed.

\section{REFERENCES}

Antkowiak I. 1996. Charakterystyka czterech genotypów bydła i ocena wydajności i jakości mleka. Poznań, Kat. Hod. Bydła AR. [in Polish]

Arbel R., Bigun Y., Ezra E., Sturman H., Hojman D. 2001. The effect of extended calving intervals in high-yielding lactating cows on milk production and profitability. J. Dairy Sci. 84, 600-608.

Chen W., Holden N.M. 2018. Briging environmental and financial cost of dairy production: A case study of Irish agricultural policy. Sci. Total Environ. DOI: 10.1016/j.scitotenv.2017.09.310.

De Vries A. 2018. Economic trade offs between genetic improvement and longevity in dairy catlle. J. Dairy Sci. 100(5), 4184-4192.

Drewnowski A. 2018. Measures'and metrics of sustainable diets with a focus on milk, yogurt and dairy products. Nutr. Rev. 1, 76(1), 21-28.

Hadley G.L., Harsh S.B., Wolf C.A. 2002. Managerial and financial implications of major dairy farm expansions in Michigan and Wisconsin. J. Dairy Sci. 85, 2053-2064.

Hogeveen H., Van Der Voorl M. 2017. Assessing the economic impact of an endemic disease: The case of mastitis. Rev. Sci. Tech. 36(1), 217-226.

Kossaibati M.A., Esslemont R.J. 1997. The costs of production diseases in dairy herds in England. The Vet. J. 154(1), 41-51.

Krpálková L., Syrǔček J., Kvapilik J., Burdych J. 2017. Analysis of milk production, age at first calving, calving interval and economic parameters in dairy cattle management. Mljekarstvo 67, 58-70.

Litwińczuk Z., Barłowska J. 2002. Polymorphism of milk proteins in Black and White and Jersey cows, its relationship to their productivity, in: Proceedings of the International Scientific Conference "Status and perspectives of Jersey cattle breeding in Poland and Europe", Poznań, June 7-8, 2001. Poznań, Wydaw. AR, 153-161.

Mosheim R., Lovell K. 2009. Scale economies and inefficiency of U.S. dairy farms. American J. Agr. Econ. 91(3), 777-794.

Mostert P.F., Bokkers E.A.M., Van Middelaar C.E., Hogeveen H., De Boer I.J.M. 2018. Estimating the economic impact of subclinical ketosis in dairy cattle using a dynamic stochastic simulation model. Animal 12(1), 145-154. 
Muhammad A., D'Souza A., Meade B., Micha R., Mozaffarian D. 2017. How income and food princes influence global dietary intakes by age and sex: evidence from 164 countries. BMJ Glob Health. 15, 2(3), 1-11. DOI: 10.1136/bmjgh-2016-000184.

Okularczyk S. 2004. Opłacalność produkcji mleka krowiego w latach 1991-2003 [Profitability of cow milk production in 1991-2003]. Rocz. Nauk. Stow. Ekon. Rol. Agrobiz. 6, 158-163. [in Polish]

Pytlewski J., Antkowiak I., Idkowiak K., Skrzypek R. 2014. Analiza opłacalności produkcji mleka w latach 2001-2012 na przykładzie RSP „Przyszłość” z uwzględnieniem zmiany systemu utrzymania krów [Analysis of profitability of milk production in 2001-2012 based on the „Przyszłość” farming cooperative in terms of changes in cow housing system]. Nauka Przyr. Technol. 8(1), 3. [in Polish]

Pytlewski J., Antkowiak I.R, Stanisławski D., Czerniawska-Piątkowska E., Nowak A.K. 2017. Analysis of profitability of raw milk production in a commercial farm before and after Poland's accession to the EU. Folia Pomer. Univ. Technol. Stetin., Agric., Aliment., Pisc., Zootech. 336(43)3, 135-144.

Sarjokari K., Hovinen M., Seppä-Lassila L., Norring M., Hurme T., Peltoniemi O.A.T., Soveri T., Rajala-Schultz P.J. 2018. On farm deaths of dairy cows are associated with features of free stall barns. J. Dairy Sci. DOI: 10.3168/jds.2017-13420.

SAS ${ }^{\circledR}$ user's guide. Statistics version 9.4 edition. 2016. Cary, NC, USA, SAS Institute.

Seegers H., Fourichon K., Beaudeau F. 2003. Production effects related to mastitis and mastitis economics in dairy herds. Vet. Res. 34, 475-491.

Sjaunja L.O., Baevre B., Junkkarienen L., Pedersen J., Setala J. 1990. A Nordic proposal for an energy-corrected milk (ECM) formula, in: 27 th Session International Committee for Recording and Productivity of milk Animals, Paris, France, July 2-6, 1990, Wageningen, The Netherlands, Eur. Assoc. Anim. Prod., 156-167.

Skrzypek R. 2001. Charakterystyka cech funkcjonalnych u bydła rasy jersey [Characterization of functional characteristics in jersey cattle]. Prz. Hod. 10, 7-10. [in Polish]

Wolf C.A. 2003. The economics of dairy production. Vet. Clin. North Am. Food Anim. Pract. 19(2), 271-293.

\section{ZALEŻNOŚCI MIĘDZY RASĄ KRÓW A RENTOWNOŚCIĄ PRODUKCJI MLEKA SUROWEGO}

Streszczenie. Celem pracy było porównanie opłacalności produkcji mleka surowego $w$ dwóch stadach krów - w stadzie krów rasy Jersey (J) i w stadzie rasy polskiej holsztyńsko-fryzyjskiej odmiany czarno-białej (PHF), należących do jednego podmiotu gospodarczego. W pracy porównano dobową rzeczywistą i standaryzowaną (FCM i VCM) wydajność mleka oraz jego skład u krów rasy J i PHF, uwzględniając podział na grupy wiekowe (pierwiastki i wieloródki). W obrębie ras J i PHF w każdym roku analizowanego okresu dokonano bilansu przychodów i kosztów produkcji mleka surowego oraz wyliczono wskaźniki produkcji, tj.: koszt całkowity wyprodukowania 1 I mleka, dochód netto z produkcji bydła, dochód netto z produkcji 1 I mleka, wartość produkcji mleka na jedną krowę oraz dochód netto na jedną krowę. Korzystniejszą rzeczywistą i w przeliczeniu na FCM i VCM dobową wydajnością mleka oraz wartością dobowej produkcji mleka charakteryzowały się pierwiastki rasy PHF $\mathrm{w}$ relacji do ich rówieśnic rasy $\mathrm{J}$. W tej grupie wiekowej krów, biorąc pod uwagę skład mleka, większą zawartością tłuszczu, białka, suchej masy oraz ilością elementów komórkowych w mleku odznaczały się pierwiastki J. Dla wieloródek, z wyjątkiem dobowej wydajności mleka FCM oraz liczby komórek somatycznych w mleku (średnie nie różniły się pomiędzy sobą istotnie), otrzymano w przypadku analizowanych parametrów podobne zależności, jakie uzyskano w przypadku pierwiastek. Porównując wskaźniki rentowności produkcji mleka surowego w latach 2014-2016 pomiędzy stadami krów rasy J i PHF, wykazano, że w roku 2014 i roku 2015, mimo niższej przeciętnej wydajności mlecznej, dochód netto z produkcji 1 I mleka był największy w stadzie krów J, natomiast w roku 2016 korzystniejszą wartością tego wskaźnika charakteryzowały się krowy rasy PHF, w odniesieniu do J. Można stwierdzić, że koszty poniesione na produkcję mleka 
surowego uzależnione są od specyficznych uwarunkowań w danym stadzie czy gospodarstwie, w związku z czym racjonalnym postępowaniem jest ciągłe obniżanie nakładów na jego wytwarzanie w powiązaniu $z$ doskonaleniem cech produkcyjnych i funkcjonalnych krów. Jeżeli koszt całkowity wyprodukowania 1 I mleka w stadzie krów ras J i PHF jest podobny, to większą opłacalnością produkcji mleka surowego charakteryzują się krowy rasy J. Wynika to z wyższej ceny uzyskiwanej za sprzedaż mleka pochodzącego od krów tej rasy.

Słowa kluczowe: ekonomika produkcji mleka, krowy jersey, krowy rasy polskiej holsztyńsko-fryzyskiej odmiany czarno-białej. 